\title{
In vitro effects of metal ions on cellular metabolism and the correlation between these effects and the uptake of the ions
}

\author{
J. C. Wataha, ${ }^{*}$ C. T. Hanks, and R. G. Craig \\ The University of Michigan School of Dentistry, Ann Arbor, Michigan 48109-1078
}

The effects of $\mathrm{Ag}^{+1}, \mathrm{Au}^{+3}, \mathrm{Cd}^{+2}, \mathrm{Cu}^{+2}, \mathrm{Ga}^{+3}, \mathrm{In}^{+3}, \mathrm{Ni}^{+2}$, $\mathrm{Pd}^{+2}$, and $\mathrm{Zn}^{+2}$ on DNA synthesis, protein synthesis, succinic dehydrogenase activity, and total cellular protein of mammalian fibroblasts were measured for exposures less than $12 \mathrm{~h}$. The rates at which these cellular functions responded to metal ion exposure were compared and related to the uptake rate of the ions into the cells. These rates of response were significantly different: DNA synthesis decreased the fastest, followed by protein synthesis, succinic dehydrogenase activity, and total protein. This order of response was similar for most metal ions.
At $4 \mathrm{~h}$, the rate of uptake of the metal ions correlated most closely with depression of succinic dehydrogenase activity, whereas at $8 \mathrm{~h}$, the uptake correlated most closely with depression of protein synthesis. The similar response of cells to all metal ions may imply that these ions act on cells by similar mechanisms. The rates of uptake of $\mathrm{Ag}^{+1}, \mathrm{Cu}^{+2}$, and $\mathrm{Zn}^{+2}$ were sufficiently fast that in vivo exposures of tissues to these metals for periods less than $12 \mathrm{~h}$ would be capable of disrupting cellular metabolism. (c) 1994 John Wiley \& Sons, Inc.

\section{INTRODUCTION}

Dental casting alloys, cements, and amalgams release a variety of metal ions that accumulate in oral tissues. ${ }^{1-8}$ Once released from dental materials, metal ions may have cytotoxic, ${ }^{9,10}$ immunogenic, ${ }^{11}$ or mutagenic effects, ${ }^{12,13}$ and there is increasing concern about the effects of these metals on local tissues. We have previously measured the cytotoxic effects of metal ions on cell metabolism in vitro. ${ }^{14}$ In these experiments, we exposed fibroblasts to metal ions for $24 \mathrm{~h}$, and measured the effects of the ions on protein synthesis, DNA synthesis, succinic dehydrogenase (SDH) activity, and total protein of the cell monolayers. Each metal ion disrupted these cellular processes at different concentrations; that is, each metal ion had a different potency. For example, the concentration of $\mathrm{Cd}^{+2}$ required to suppress $\mathrm{SDH}$ activity by $50 \%$ was $1.1 \mu \mathrm{M}$, whereas $360 \mu \mathrm{M}$ of $\mathrm{Pd}^{+2}$ was required to cause a similar effect. However, for a given metal, the four processes were often affected at similar concentrations. When these processes were affected

${ }^{*}$ To whom correspondence should be addressed. at different concentrations, the concentration that affected SDH activity was midrange among the others.

In a second study, we measured the uptake of eight metal ions into cells after $8 \mathrm{~h}$ of exposure as a function of concentration of the metal ions in the cell-culture medium. ${ }^{15}$ The tendency of cells to take up these ions varied by 400 times among metals. Furthermore, metals that suppressed SDH activity at low concentrations tended to be taken up more efficiently by cells than metals that suppressed SDH at higher concentrations. However, we could not clearly establish the relationship between the effects of the metal ions and their uptake because we measured SDH activity at $24 \mathrm{~h}$ and metal uptake at $8 \mathrm{~h}$, and we did not measure the dynamics of these processes.

The aim of the current study was to extend our previous work by measuring the metabolic effects of metal ions and their uptake by cells as a function of time. By correlating the rates of uptake of the metals with the cellular metabolic functions during the uptake, we hoped to establish which cellular functions could be related to the uptake of the ions. A good correlation would provide a basis for more in-depth studies on the mechanisms by which these ions act in cells. 


\section{MATERIALS AND METHODS}

\section{Cell-culture and metal ion solutions}

Balb/c 3T3 mouse fibroblasts (ATCC CCL 163, clone A31) were maintained in cell-culture medium consisting of Dulbecco's Modified Eagle's medium, 3\% NuSerum, HEPES ( $N$-2-hydroxyethyl piperazine- $N^{\prime}-2-$ ethanesulfonic acid, $\mathrm{pH}=7.2,28 \mathrm{mmol} / \mathrm{L})$, penicillin $(125 \mathrm{U} / \mathrm{mL})$, streptomycin $(125 \mu \mathrm{g} / \mathrm{mL})$, gentamycin $(10 \mu \mathrm{g} / \mathrm{mL})$, and glutamine $(2 \mathrm{mmol} / \mathrm{L})$. The HEPES controlled the $\mathrm{pH}$ of the medium to within $0.05 \mathrm{pH}$ units when the metal ions were added. The native medium was checked for traces of metal ions by means of atomic absorption spectroscopy. Zinc was present at 0.01 parts per million. All other ions were below detection limits ( 20 parts per billion). The cells were harvested from pre-confluent flasks and diluted to the appropriate concentration before they were plated.

The metal ions and their sources are listed in Table I. These ions were chosen because they are released from dental alloys, cements, and amalgams into the oral cavity. ${ }^{1-8}$ Purities of the metal ions were greater than 99.9\%. Aqueous solutions of the ions were prepared as previously described, ${ }^{14}$ and control solutions consisted of the sodium salts of the appropriate anions. The effects of all metal ions on cellular metabolism were tested, but the uptake of gold and gallium into cells was not measured because of the relatively poor sensitivities of flame atomic absorption to these metals.

The concentrations of the metal ions that we used in these experiments (Table I) were based on previous work, which showed that these concentrations had similar metabolic effects on cells after $24 \mathrm{~h}$ exposure. ${ }^{14}$ In our previous work, we exposed a series of concentrations of each metal ion to cells for $24 \mathrm{~h}$, and then measured the effects of the metal ions on succinic dehydrogenase activity, DNA synthesis, protein synthesis, and total protein content. In the current study, we used a single concentration and measured cellular

\section{TABLE I}

Information on Metal Ions

\begin{tabular}{crcc}
\hline Ion & $\mathrm{AW}^{*}$ & \multicolumn{1}{c}{ Source } & Conc. Tested $(\mu \mathrm{mol} / \mathrm{L})$ \\
\hline $\mathrm{Ag}^{+1}$ & 107.9 & $\mathrm{Ag}_{2} \mathrm{SO}_{4}$ & 7.0 \\
$\mathrm{Au}^{+3}$ & 197.0 & $\mathrm{HAuCl}_{4} \cdot 3 \mathrm{H}_{2} \mathrm{O}$ & 100 \\
$\mathrm{Cd}^{+2}$ & 112.4 & $\mathrm{CdCl}_{2}$ & 0.90 \\
$\mathrm{Cu}^{+2}$ & 63.5 & $\mathrm{CuCl}_{2}$ & 240 \\
$\mathrm{Ga}^{+3}$ & 69.7 & $\mathrm{Ga}\left(\mathrm{NO}_{3}\right)_{3}{ }^{+}$ & 290 \\
$\mathrm{In}^{+3}$ & 114.8 & $\mathrm{InCl}_{3}{ }^{+}$ & 435 \\
$\mathrm{Ni}^{+2}$ & 58.7 & $\mathrm{NiCl}_{2} \cdot 6 \mathrm{H}_{2} \mathrm{O}$ & 200 \\
$\mathrm{Pd}^{+2}$ & 106.4 & $\mathrm{PdCl}_{2}$ & 280 \\
$\mathrm{Zn}^{+2}$ & 65.4 & $\mathrm{ZnCl}_{2}$ & 30
\end{tabular}

${ }^{*}$ Atomic weight.

${ }^{+}$From atomic absorption solution. metabolism at several times before $24 \mathrm{~h}$. For each metal ion, we selected concentrations that inhibited these cellular functions by $50 \%$ after $24 \mathrm{~h}$. It was not possible to select the same concentration for all metals because the potencies of the metals varied by over 400 times. By using equivalent potencies, we could compare the effects for different metal ions.

\section{Effects of metal ions on cell metabolism}

The cells were plated into 24 -well polystyrene cellculture plates at $20,000 \mathrm{cells} / \mathrm{cm}^{2}$ in $1.0 \mathrm{~mL}$ of medium. Six replicate wells were prepared for each time period and cellular function. After incubation for $24 \mathrm{~h}$ at $37^{\circ} \mathrm{C}, 5 \% \mathrm{CO}_{2}$, and $100 \%$ relative humidity, $20 \mu \mathrm{L}$ of the metal ion solutions was added to the wells. No precipitation was noted in the medium after the metal ions were added. Control wells received $20 \mu \mathrm{L}$ of the appropriate sodium-anion salt. After addition of the metal ions or corresponding anions, the cells were incubated for 4,8 , and $12 \mathrm{~h}$ before the cellular metabolism was evaluated. To establish baseline values for the metabolic functions, wells without anions or metal ions were evaluated in a separate cell-culture plate at the time of metal ion addition ( 0 -h values). Selected experiments were repeated to ensure reproducibility. The effects of $\mathrm{In}^{+3}$ were not assessed, because $\mathrm{In}^{+3}$ concentrations up to $435 \mu \mathrm{mol} / \mathrm{L}$ had no effect on fibroblasts in preliminary experiments.

Four cellular metabolic functions were measured. Mitochondrial succinic dehydrogenase activity was measured by the production of the formazan of 3-[4,5-dimethyl-thiazol-2yl-]-2,5-diphenyl tetrazolium bromide (MTT-f) from MTT in the presence of a disodium succinate substrate. Protein synthesis was estimated by incorporation of tritiated leucine, and DNA synthesis was estimated by incorporation of tritiated thymidine. Finally, the total soluble protein (TP) present in the monolayer was measured by a commercial assay (bicinchoninic acid [BCA]; Pierce, Rockford, IL). Details of these methods have been described previously. ${ }^{14}$

\section{Uptake rates of metal ions}

Cells were plated into $75 \mathrm{~cm}^{2}$ polystyrene cellculture flasks at 20,000 cells $/ \mathrm{cm}^{2}$ in $15 \mathrm{~mL}$ of medium. After incubation for $24 \mathrm{~h}$, solutions of the metal ions were added to the flask to provide the desired concentrations (Table I). Concentrations of the metal ions were chosen to correspond to those used in experiments that measured the effects of the ions on cellular metabolism. For $\mathrm{In}^{+3}$, the maximum concentration that would not precipitate was used. The flasks were then incubated for $15 \mathrm{~min}$, or 1,2 , 4 , or $8 \mathrm{~h}$, after which the amounts of the metal ions 
taken up by the cells were determined. Periods of $8 \mathrm{~h}$ or less were chosen because pilot experiments had shown that cellular growth or detachment were minimal during this time, and these time periods corresponded to the cell metabolism experiments. The control flasks were processed at time "zero," that is, the time at which the metal ions were added to the other flasks. To determine the precision of the data, multiple flasks were used for selected times.

After incubation with the metal ion, the medium covering the cells was removed from the flasks, and the monolayer was washed 6 times with phosphatebuffered saline solution. Pilot studies established that flame atomic absorption could not detect metal ions in the fifth wash; the sixth wash was added as a precaution. This sixth wash was analyzed by means of atomic absorption in each experiment to verify the efficacy of the washing procedure. After washing, the cells were released from the flask using $1.5 \mathrm{~mL}$ of a trypsin-EDTA solution. The trypsin was then quenched with an equal volume of medium, and the cell suspension was mixed thoroughly. A $50 \mu \mathrm{L}$ sample of the suspension was removed for cell counting (Coulter counter). The remainder of the suspension was centrifuged at $200 \times g$ for $4 \mathrm{~min}$ to separate the cells. To determine the extent of cell and metal ion loss during this procedure, the supernatant liquid was carefully removed and was analyzed for cells and metal ions. Cell counts and metal ion concentrations were below detectable levels. Double-distilled water $(0.5 \mathrm{~mL})$ was added to the cell pellet, and the pellet was dispersed by vortexing for 30 seconds, then treated ultrasonically for 60 seconds. Microscopic examination of the resulting liquid showed no evidence of cells, and the solution appeared clear. These liquids were then analyzed for metal ions by means of atomic absorption. Details of atomic absorption procedures have been previously published. ${ }^{15}$ The detection limits for the metal ions, adjusted to reflect the minimum amount of metal ion detectable per cell, are listed in Table II. The phosphate-buffered saline solution, distilled water, and trypsin solution were tested to ensure that the levels of metal ions in these solutions were below detection limits.

\section{Calculations and statistics}

For experiments that measured the effects of the metal ions on cellular metabolism, the percentage change between the control and the metal-containing culture was calculated after 4,8 , and $12 \mathrm{~h}$ for each cellular function. Confidence intervals $(P=.05)$ were also determined.

For experiments that measured the rate of uptake of metal ions by cells, the average quantity of the metal ion per cell was determined by dividing the quantity of the ion in the cell-pellet by the number of cells in the pellet. Control flasks, without metal ions, were used to determine the amount, if any, of the metal ions that were present in the cells normally (Normal Amount in Table II). If no metal ions were present above detection limits, then the amount normally present was listed as less than the detection limit. The uncertainty in the cellular metal ion levels was $10 \%$ (at $P=.05$ ) based on pilot experiments that used replicate flasks. The rate of uptake of each metal ion was determined by plotting the quantity of the ion per cell versus time, then fitting a linear least squares line to the data. This slope had units of $\mathrm{fmol} / \mathrm{cell} / \mathrm{h}$. Linear regression analysis was used to determine whether the slope was significantly different from zero. The correlation between the uptake rate and cellular function was also determined by linear regression analysis.

\section{RESULTS}

Figure 1 shows the effect of the metal ions on the total protein (TP), DNA synthesis (DNA), protein synthesis (Pro), and SDH activity (SDH) over $12 \mathrm{~h}$. From this drawing, it is apparent that cellular functions

TABLE II

Detection Limits, Normal Cellular Concentrations, and Uptake Rates for Metal Ions

\begin{tabular}{lcccc}
\hline Ion & Detection Limit (fmol/cell) & Normal Amount ${ }^{*}(\mathrm{fmol} / \mathrm{cell})$ & Uptake Rate $^{+}(\mathrm{fmol} / \mathrm{cell} / \mathrm{h})$ & $R^{2}$ \\
\hline $\mathrm{Ag}^{+1}$ & 0.020 & $<0.020$ & 0.16 & 0.97 \\
$\mathrm{Cd}^{+2}$ & 0.019 & $<0.019$ & 0.089 & 0.99 \\
$\mathrm{Cu}^{+2}$ & 0.037 & 0.094 & $>8.0$ & 0.99 \\
$\mathrm{In}^{+3}$ & 1.60 & $<1.60$ & 0.043 & $\mathrm{NA}$ \\
$\mathrm{Ni}^{+2}$ & 0.077 & $<0.077$ & 0.012 & 0.97 \\
$\mathrm{Pd}^{+2}$ & 0.090 & $<0.090$ & 0.21 & 0.60 \\
$\mathrm{Zn}^{+2}$ & 0.020 & 1.02 & 0.99 \\
\hline
\end{tabular}

* Average quantity of a metal ion in a control cell. Uncertainty in these and other concentrations are $10 \%$ at $P=.05$ based on pilot experiments that tested precision.

${ }^{\dagger}$ Least squares linear slope of the ion concentration versus time curve over $8 \mathrm{~h} . R^{2}$ (next column) indicates the percentage of variability explained by the linear model. For comparison, slope for In is an estimate of the initial increase in cellular concentration, as the curve was not linear over the $8 \mathrm{~h}$ period. 


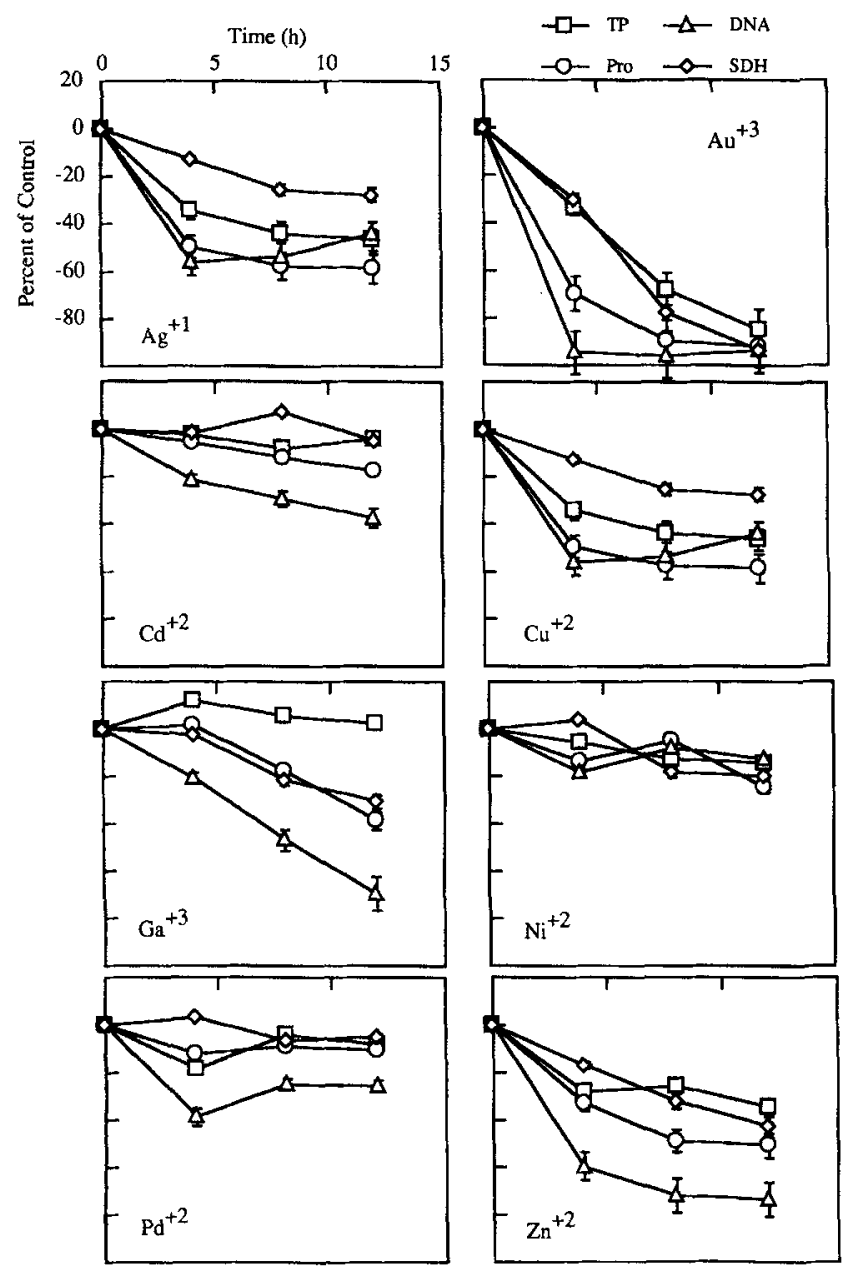

Figure 1. The effects of metal ions on DNA synthesis (DNA), protein synthesis (Pro), succinic dehydrogenase (SDH) activity, and total protein (TP) over $12 \mathrm{~h}$ of exposure. Cellular functions are expressed as a percentage of a control group to which no metal ions were added. Error bars represent three standard errors of the mean at $P=.05$. Cell functions were inhibited at different rates, but the order of the decrease was generally similar among metals.

did not decrease at the same rates when exposed to these metal ions. DNA synthesis always decreased the fastest, but the sequence of the other cellular functions varied. With some metal ions $\left(\mathrm{Cu}^{+2}, \mathrm{Ni}^{+2}, \mathrm{Pd}^{+2}\right.$, and $\mathrm{Zn}^{+2}$ ), the sequence was not uniform with time. The rates of decrease varied among the metal ions, despite the use of concentrations that produced $50 \%$ SDH activity after $24 \mathrm{~h}$ for each metal.

Figure 2 shows the uptake of the metal ions over time. Except for $\mathrm{In}^{+3}$, the uptake of the metal ions appeared linear over $8 \mathrm{~h}$. This allowed the determination of a single slope to represent the uptake rate. Table II lists these uptake rates and the $R^{2}$ values for the lines that were used to calculate the uptake rates. The high $R^{2}$ values indicated that the linear model explained most of the variation in amount of metal taken up by the cell over time. The $R^{2}$ value for $\mathrm{Pd}^{+2}$ was lower because of $\mathrm{Pd}^{+2}$ s low uptake slope. Regression analysis indicated that all slopes except $\mathrm{Pd}^{+2}$ were probably non-zero $(P<.001)$. The $P$ value for $P^{+2}$ was .07 . Although not shown in Figure $2, \mathrm{In}^{+3}$ increased linearly until $4 \mathrm{~h}$, then leveled off over the next $4 \mathrm{~h}$. For this reason, the uptake rate was listed at $>8.0 \mathrm{fmol} / \mathrm{cell} / \mathrm{h}$. As Table II and Figure 2 show, the uptake rates for the metal ions were diverse. The slowest rate was for $\mathrm{Pd}^{+2}$ at $0.012 \mathrm{fmol} / \mathrm{cell} / \mathrm{h}$, whereas the fastest rate was for $\mathrm{In}^{+3}$, more than 100 times greater. Furthermore, Table II shows that as expected, $\mathrm{Cu}^{+2}$ and $\mathrm{Zn}^{+2}$ were detectable as normal constituents of cells.

Figure 3 shows the correlation between the cellular uptake of the metal ions and the effects of the ions on cellular metabolism at 4 and $8 \mathrm{~h}$. For each correlation, the $R^{2}$ value indicates the percentage of variation explained by the linear model, and the $P$ value indicates the probability that the correlation was zero. After $4 \mathrm{~h}$, the SDH activity correlated most closely with metal ion uptake $\left(R^{2}=0.81 ; P=.02\right)$. The other cellular functions also correlated with uptake, but to a lesser degree. After $8 \mathrm{~h}$, the protein synthesis correlated most closely with cellular uptake $\left(R^{2}=0.85\right.$; $P=.01)$. A comparison between uptake rates and cellular metabolisms after $12 \mathrm{~h}$ are not shown because uptake rates could not be measured at $12 \mathrm{~h}$. At times greater than $8 \mathrm{~h}$, cellular division and loss of cells from the toxic effect of the metals interfered with the measurement of uptake.

\section{DISCUSSION}

The correlation of SDH activity and protein synthesis with the uptake rate of the metal ions implies that these cellular functions may be initially involved in the mechanism of action of metal ions on fibroblasts. Because SDH activity occurs in the mitochondria, these results imply that the mitochondria may be affected first by the metal ions. Witschi and Aldridge reported that beryllium taken up by rat liver cells over $5 \mathrm{~h}$ was associated with a mitochondrial fraction. ${ }^{16}$ However, they also reported that it appeared that the majority of the beryllium was bound by lysosomes in this fraction. These investigators did not measure mitochondrial function during the beryllium exposure. Their results imply that the function of mitochondria may not be directly affected by beryllium. The extrapolation of their results to the current study is tenuous, because different cells and metal ions were used, but it demonstrates that the correlations observed in the current study may not imply direct effect. More recently, Ueno et al. have reported that $\mathrm{Cr}^{+6}$ and $\mathrm{Cr}^{+3}$ progressively accumulated in the mitochondrial fraction of hepatocytes over $60 \mathrm{~min} .{ }^{17}$ This observation is consistent with the current study because the uptake rate in our experiments correlated most closely with 


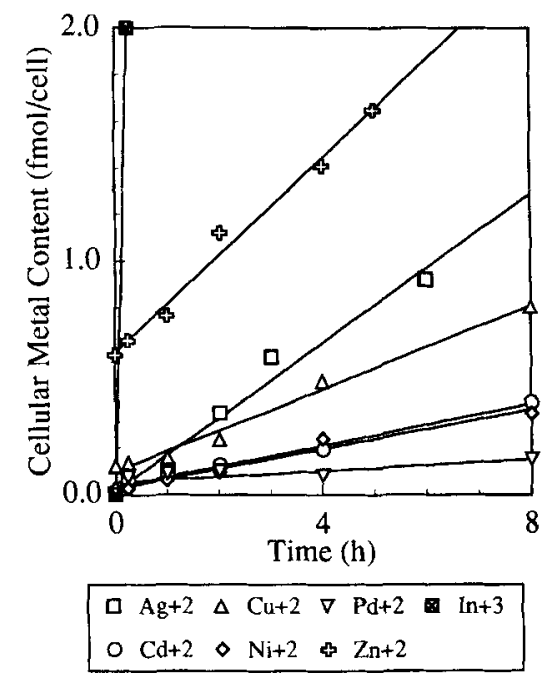

Figure 2. The average cellular content of the metal ions as a function of time. The lines represent least squares linear best fits of the data. Values for $R^{2}$ are listed in Table II. The uptake of the ions was generally linear, except for $\mathrm{In}^{+3}$, which leveled off between 4 and $8 \mathrm{~h}$ (not shown). The rates of uptake, represented by the slopes of the curves, were significantly different among metals. As expected, $\mathrm{Zn}^{+2}$ and $\mathrm{Cu}^{+2}$ had non-zero $y$-intercepts because these metals are normally present in cells.

decreases SDH activity at $4 \mathrm{~h}$. Webb and Weinzierl reported that about $22 \%$ of ${ }^{63} \mathrm{Ni}^{+2}$ taken up by mouse dermal fibroblasts was located in the mitochondria after $24 \mathrm{~h}$, whereas $36 \%$ was located in the nucleus and about $25 \%$ was located in the cell sap fraction. ${ }^{18}$ However, they did not measure the distribution at earlier times. Nonetheless, their work demonstrates that metal ions bind to the cytosolic organelles.

Figure 1 shows that the order in which the four cell functions were effected was generally similar among metals. Furthermore, the correlation between uptake rate and cellular dysfunction held for several metals (Fig. 3). The common order of effect and the correlation between uptake and effect support the idea that these metal ions act through common mechanisms. Williams has stated that the toxicity of these types of metals are caused by the formation of complexes of the metal ions with cellular components that subsequently disrupt essential biochemical reactions. ${ }^{19}$ Because the metal ions in the current study appear to disrupt cellular functions in similar ways, these metal ions may form complexes in similar ways in the cell. The variation in toxic effects among metals is probably due to differences in the strengths or nature of these complexes. Although the data in Figures 1 and 3 show similar patterns and correlation among metals, these correlations are far from ideal, and the variations may be caused by differences in the binding properties of the individual ions. We have previously shown that the overall cellular affinities of these metal ions are diverse and correlate with the potency of the ions. ${ }^{15}$
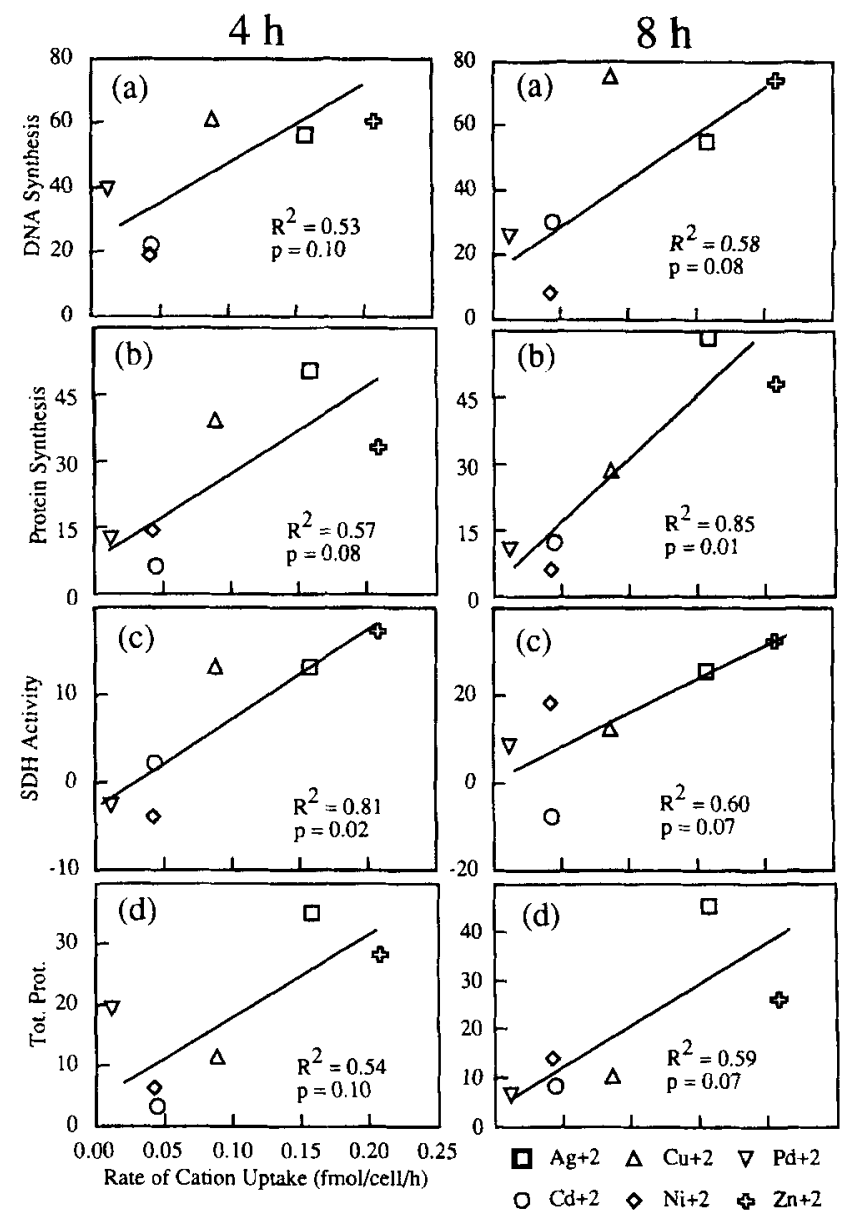

Figure 3. The correlation between the uptake rate of a metal ion by cells and the degree of cellular inhibition of (a) DNA synthesis, (b) protein synthesis, (c) SDH activity, and (d) total cellular protein after $4 \mathrm{~h}$ and $8 \mathrm{~h}$ of metal ion exposure. The $x$-axes show the rate of uptake of the metal ions (in Table II), which was the slope of the cellular-uptake versus time plots in Figure 2. The $y$-axes show the percent inhibition of the cellular activity caused by the metal ions. Negative inhibitions, seen in (c), reflection stimulation of the cellular activity by the metal ions. Values for $R^{2}$ and $\mathrm{P}$ pertain to the least squares linear model used to draw the line. At $4 \mathrm{~h}$, uptake rates correlated best with SDH activity (c), although there was some correlation with the other cellular functions. At $8 \mathrm{~h}$, uptake rates correlated best with protein synthesis (b).

It appears contradictory that metal uptake would correlate best with SDH activity at $4 \mathrm{~h}$ (Fig. 3) while the DNA synthesis at this time has decreased far more than SDH activity. We can offer no experimentally supported explanation. However, because DNA synthesis demands much of the cells energy in an exponentially growing cell-culture, ${ }^{20}$ it is reasonable to speculate that disruption of mitrochondrial function would adversely and immediately affect DNA synthesis. Figure 3 shows some correlation between all of the cell functions and metal ion uptake, and given the dependence of these cell processes on one another, some correlation is not surprising. 
Two factors limit the interpretation of these experiments. First, the status of the cell-cycle in the cells probably had an important role in the response of these cells to the metal ions. Although we used cultures in the growth phase, it is important to recognize that the cells were not synchronized with regard to cell-cycle. Thus, our data represent an average response, and future experiments using synchronized cultures may provide more insight about the effect of cell cycle on the cytotoxic response. Second, we used a continuous cell line rather than a primary cell line. Although we believe that the observations we have reported are important to understanding the mechanisms of the response of cells to metal ions, it is likely that in vivo, cells may respond somewhat differently because of different bioavailability or additional cellular detoxification strategies.

Several groups of researchers have reported that the release of metal ions from casting alloys, ${ }^{3,4,21}$ and amalgam $^{22}$ is greatest before the surfaces of these materials passivate. Thus, the potential of the released metal ions to cause problems in tissues adjacent to these restorations is greatest for relatively short periods ( $<24 \mathrm{~h}$ ) of time before passivation occurs, or after a passivated surface is disrupted. Because the metal ions are present for short periods of time, the uptake rate of the ions into cells is important. The current study demonstrates that several metal ions that are known to be released from materials can be taken up into cells in this time frame, and these ions will interfere with cellular metabolism during this time. Merritt et al. have shown that some metals such as titanium are not readily excreted after introduction into tissues, ${ }^{23}$ and thus may tend to accumulate in tissues over time. At the cellular level, the buildup of ions would depend on the reversibility of the uptake. Although we have shown that some metal ions such as $\mathrm{Cd}^{+2}$ and $\mathrm{Ni}^{+2}$ do not leave fibroblasts as fast as they were taken up, ${ }^{15}$ the reversibility of the effects of these ions and their long-term effects remain largely unstudied.

Because different concentrations were used for each metal ion in the current study (Table I), it might appear that the different uptake rates observed in Table II were simply a function of these different concentrations. However, comparison of Tables I and II clearly show that this is not true. For example, $\mathrm{Pd}^{+2}$ had the slowest uptake rate of all the metal ions studied, yet its concentration in the cell-culture medium was among the highest used. $\mathrm{Ag}^{+1}$ had the third highest uptake rate, yet its concentration in the medium was among the lowest used. Thus, uptake rates, although probably influenced by the external concentration in the cell-culture medium, were also a function of the interaction between the cell and the ions. Although it would have been less confusing to use a single concentration for all metal ions, it was not possible because these metal ions have their cellular effects at greatly different concentrations. Thus, to demonstrate a correlation between uptake rates and biological effects, we selected metal in concentrations that had equivalent functional effects.

We selected concentrations of the metal ions based on the ability of the metal ion to reduce SDH activity $50 \%$ after $24 \mathrm{~h}$ of exposure. Figure 1 shows that after $12 \mathrm{~h}$, the SDH decreased varied among metals, indicating that the decay of cellular function in response to metal ion exposure is not linear with respect to time. This observation is consistent with our previous results, which showed that cellular functions are not necessarily inhibited proportionally with the duration of exposure. ${ }^{24}$ Thus, when ranking the toxicity of these ions, it is paramount to specify the duration of exposure and the means of assessing the toxicity.

In summary, these metal ions disrupt DNA synthesis, protein synthesis, succinic dehydrogenase activity, and total protein at different rates in the first $12 \mathrm{~h}$ of exposure, and the uptake rates of the ions by the cells correlates most closely with the succinic dehydrogenase activity and protein synthesis during this time. These correlations may imply that the mechanisms of action of these ions act in a similar fashion. Furthermore, the uptake rates of $\mathrm{Ag}^{+1}, \mathrm{Cu}^{+2}$, and $\mathrm{Zn}^{+2}$ are sufficiently fast that cells would be able to take up sufficient quantities of these ions to disrupt cellular metabolism when dental restorations release these ions. Studies that correlate the uptake rates of ions into subcellular fractions with the activity of these fractions would help clarify the mechanism of action of these metal ions. Studies exploring the effect of cell-cycle and primary cell lines would also be useful.

The authors thank Dr. Richard Corpron and Pat Landry for allowing them to use the atomic absorption spectrophotometer. They also thank Jackie Dahlgren and Susan Strawn for their assistance in the laboratory. Finally, they thank the National Institute for Dental Research for their support of this project through Grants DE05584 and DE09296.

\section{References}

1. D. Brune, "Metal release from dental biomaterials," Biomaterials, 7, 163-175 (1986).

2. S. A. Brown, L. J. Farnsworth, K. Merritt, and T.D. Crowe, "In vitro and in vivo metal ion release," J. Biomed. Mater. Res., 22, 321-338 (1988).

3. J. Geis-Gerstorfer, K.H. Sauer, and K. Pässler, "Ion release from $\mathrm{Ni}-\mathrm{Cr}-\mathrm{Mo}$ and $\mathrm{Co}-\mathrm{Cr}-\mathrm{Mo}$ casting alloys," Int. J. Prosthodont., 4, 152-158 (1991).

4. J.C. Wataha, R. G. Craig, and C.T. Hanks, "The release of elements of dental casting alloys into cellculture medium," J. Dent. Res., 70, 1014-1018 (1991).

5. T. Stenberg, "Release of cobalt from cobalt chromium alloy constructions in the oral cavity of man," Scand. J. Dent. Res., 90, 472-479 (1982). 
6. S. Q. Hao and J. E. Lemons, "Histology of dog dental tissues with Cu-based crowns," J. Dent. Res., 68(SI), 322, Abstr. \#1125 (1989).

7. C. Wallman, J. Afseth, and C.G. Emilson, "Copper in approximal plaque from conventional and non-gamma-2 amalgam restorations," Acta. Odontol. Scand., 50, 79-82 (1992).

8. P. Rechmann, "Lamms and ICP-MS detection dental metallic compounds in not-discoloured human gingiva," J. Dent. Res., 71, 599, Abstr. \#672 (1992).

9. J.D. Bumgardner, L.C. Lucas, and A.B. Tilden, "Toxicity of copper-based dental alloys in cell culture," J. Biomed. Mater. Res., 23, 1103-1114 (1989).

10. M. Kaga, N.S. Seale, T. Hanawa, J. L. Ferracane, and T. Okabe, "Cytotoxicity of amalgams," J. Dent. Res., 67, 1221-1224 (1988).

11. L. Greppi, D.C. Smith, D. G. Woodside, and T. Varrela, "Nickel hypersensitivity reactions in orthodontic patients," J. Dent. Res., 70(SI), 361, Abstr. \#768 (1991).

12. T. P. Coogan, D. M. Lattaa, E. T. Snow, and M. Costa, "Toxicity and carcinogenicity of nickel compounds," Crit. Rev. Toxicol., 19, 341-384 (1989).

13. A. A. Jensen and F. Tüchsen, "Cobalt exposure and cancer risk," Crit. Rev. Toxicol., 20, 427-437 (1990).

14. J.C. Wataha, C.T. Hanks, and R.G. Craig, "The in vitro effects of metal cations on eukaryotic cell metabolism," J. Biomed. Mater. Res., 25, 1333-1149 (1991).

15. J.C. Wataha, C. T. Hanks, and R.G. Craig, "Uptake of metal cations by fibroblasts in vitro," J. Biomed. Mater. Res., 27, 227-232 (1993).

16. H.P. Witschi and W.N. Aldridge, "Uptake, distribution, and binding of beryllium to organelles of the rat liver cell," Biochem. J., 106, 811-820 (1968).
17. S. Ueno, N. Susa, and Y. Furukawa, "Uptake and distribution of chromium in isolated rat hepatocytes and its relation to cellular injury," Kitasato Arch. Exp. Med., 63, 49-57 (1990).

18. M. Webb and S.M. Weinzierl, "Uptake of ${ }^{63} \mathrm{Ni}^{2+}$ from its complexes with proteins and other ligands by mouse dermal fibroblasts in vitro," $\mathrm{Br}$. J. Cancer, 26, 292-298 (1972).

19. D.F. Williams, "The toxicology of implanted metals," in: D.F. Williams (ed.), Fundamental Aspects of Biocompatibility, Vol. II, CRC Press, Boca Raton (1981).

20. L. Stryer, Biochemistry, W.H. Freeman, New York (1988).

21. V. Goehlich and M. Marek, "Corrosion behavior of Pd-Cu and Pd-Co alloys in synthetic saliva," Dent. Mater., 6, 103-110 (1990).

22. M. Marek, "The release of mercury from dental amalgam: The mechanisms and in vitro testing," J. Dent. Res., 69, 1167-1174 (1990).

23. K. Merritt, R.W. Margevicius, and S.A. Brown, "Storage and elimination of titanium, aluminum, and vanadium salts, in vivo," J. Biomed. Mater. Res., 26, 1503-1515 (1992).

24. J. C. Wataha, C. T. Hanks, and R. G. Craig, "In vitro synergistic, antagonistic, and duration of exposure effects of metal cations on eucaryotic cells," J. Biomed. Mater. Res., 26, 1297-1309 (1992).

Received May 20, 1993

Accepted October 22, 1993 